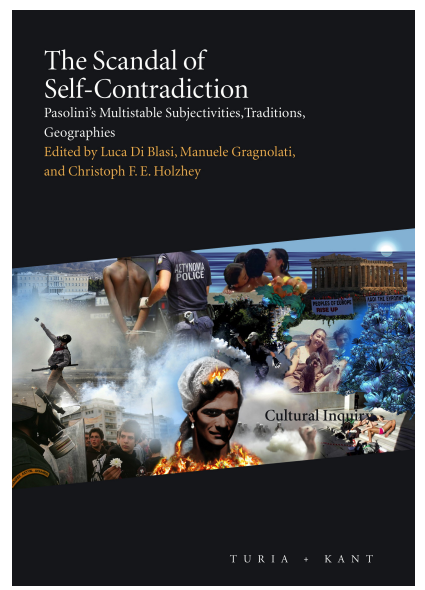

The Scandal of Self-Contradiction: Pasolini's Multistable Subjectivities, Geographies, Traditions, ed. by Luca Di Blasi, Manuele Gragnolati, and Christoph F. E. Holzhey, Cultural Inquiry, 6 (Vienna: Turia + Kant, 2012), pp. 85-103

PREVIOUSLY PUBLISHED AS:

| Identical except for DOI prefix 10.25620

\section{AGNESE GRIECO}

\section{The Body of the Actor}

Notes on the Relationship between the Body and Acting in Pasolini's Cinema

CITE AS:

Agnese Grieco, 'The Body of the Actor: Notes on the Relationship between the Body and Acting in Pasolini's Cinema', in The Scandal of Self-Contradiction: Pasolini's Multistable Subjectivities, Geographies, Traditions, ed. by Luca Di Blasi, Manuele Gragnolati, and Christoph F. E. Holzhey, Cultural Inquiry, 6 (Vienna: Turia + Kant, 2012), pp. 85-103 <https://doi.org/10.37050/ci-06_05>

\section{RIGHTS STATEMENT:}

(C) by the author(s)

This version is licensed under a Creative Commons AttributionShareAlike 4.0 International License.

ABSTRACT: What is the role or the function of the actor in Pasolini's cinema? I shall try to put this very general and generic question in another way: how can we define, overall, the particular physiognomy of a Pasolini actor? There are undoubtedly some particular characteristics, but what are they exactly? 


\title{
THE BODY OF THE ACTOR
}

\author{
Notes on the Relationship between \\ the Body and Acting in Pasolini's Cinema
}

Agnese Grieco

\begin{abstract}
The purest language that there is in the world, actually the only one which can be called just LANGUAGE, is the language of natural reality.

(Empirismo Eretico)
\end{abstract}

What is the role or the function of the actor in Pasolini's cinema? I shall try to put this very general and generic question in another way: how can we define, overall, the particular physiognomy of a Pasolini actor? There are undoubtedly some particular characteristics, but what are they exactly? As a director, Pier Paolo Pasolini worked with widely differing types of actors. In fact, his actors were often of completely opposing types: the great comic actor, Totò, the divas Maria Callas and Anna Magnani, the Hollywood idol Orson Welles, the 'bourgeois actor' Massimo Girotti, the young Carmelo Bene, and Julian Beck, the cofounder of the Living Theatre. With actresses such as Silvana Mangano and Laura Betti, Pasolini enjoyed a long working relationship, more than just a friendship, which should not be forgotten. And these are just a few examples.

On the other hand, and in parallel with this, Pasolini also created his own type of actor: an excellent vehicle for his poetic style of cinematography, but not merely that. One example is the curly-haired Ninetto Davoli, whose smile and funny walk with joyful little jumps, which Pasolini interpreted as having a powerful anthropological message, form one of the unmistakable images of Pasolini's films. The same can be said of Franco Citti, who brought Greek tragedy to the outskirts of Rome, or for Mario Cipriani, who plays Stracci in La ricotta.

Pasolini also often worked with non-professional actors, as did Robert Bresson and other avant-garde directors in the same period. And even these non-professionals are quite different from one another. Together with working-class city boys and ordinary folk, who could be inhabitants of any village in 'the poor, ancient country of Italy', the director cast famous intellectuals such as Cesare Musatti and even writ- 
ers (Alberto Moravia, Giuseppe Ungaretti, and Alfonso Gatto). Sometimes he interviewed them; other times he made them act. And, last but not least, he cast friends and members of his family. Pasolini's mother, for example, played Christ's mother in Il Vangelo secondo Matteo, a movie where Jesus has the El Greco-like face of a Catalan university student. Also in this film, appearing alongside the 'street people', we see the writers Natalia Ginzburg and Rodolfo Wilcock, as well as the young philosopher Giorgio Agamben and, once again, the poet Alfonso Gatto in the role of Apostles. ${ }^{1}$

It must not be forgotten that Pasolini's portrayal of the 'common people' is not limited within his cinema to the 'human territory' of Italy and Europe. Pasolini the traveller sometimes filmed faces and bodies in India and Africa for his documentaries and fiction films; he also used Afro-Americans and Asians in his works. It was in the sixies that the avant-garde theatre turned firmly towards non-European cultures through its rereading of the classical and Elizabethan repertoires and its confrontation with new dramatic structures. In the theatre, Peter Brook gave the part of Hamlet to William Nadylam, a French actor whose father was from Cameroon and whose mother was Indian, while Prospero was played by a North African; similarly, Ariane Mnouchkine opened her theatre research laboratory to Oriental styles, a fact which now belongs to the history of theatre. At the same time, Pasolini's cinematic gaze, both attentive and receptive, also seems to be in love with the beauty and meaning represented in his stories, which could only be embodied by non-actors and actors coming from the Third World in the widest sense of the term. In Appunti per un'Orestiade Africana, for instance, Pasolini - at once the director of the film and the director in the film - decides to discuss openly with us, his audience, the delicate subject of choosing the right actors for Aeschylus' famous characters. He shows us some of the possible options for Orestes, Clytemnestra, and Electra, asking us what we think of them. For the Erinyes he suggests casting a wounded lioness or the trees of the savannah: possible actors themselves, just right for the roles. In Appunti per un'Orestiade africana we also see a certain openness, which I would consider 'enlightened' in its intention to share the act of filmmaking with the audience. This is in accordance with Pasolini's unmistakable, almost erotic passion for teaching, which can be felt in the director's voice commenting upon his travels through Africa, which comprise at the same time a voyage through our Western culture: a culture and a cul- 
tural education which Pasolini will not renounce, even though he feels their limitations and weakness, as they represent for him a key for interpreting the world.

In theatre it is often said that choosing the cast in a play constitutes more than half of the director's job. What then? What path did Pasolini take here?

\section{POST-BRECHTIAN VARIATIONS}

It seems that Pasolini wants to force us - in some cases quite purposefully, at other times in a more subtle way - to step out of our prescribed role as passive spectators. The aim is to turn us into critical witnesses, fully conscious, if not in fact participating - as in the Appunti per un'Orestiade africana or Il Vangelo or La ricotta - in what is, basically, the act of creating a fictional work of cinema.

(It is important to pause here to consider the true sense of the word fiction, since it is between fiction and reality that the aesthetic and metaphysical - and not least political - game is played in Pasolini's cinema.) The message here concerns the audience, but I ask again, what about the actors?

This is not an essay about Pasolini's cinema. Before I go on, I must therefore apologize to the reader for the hybrid style and the sheer pace of this piece, which must seem rather casual at times. At least that is how it seems to me rereading what I have written. I am aware of this, but these are supposed to be working notes, or rather observations arising from questions about theory which are part of my work as a director and a playwright, especially in the context of trying to find a way to bring Pasolini's world to the stage. ${ }^{2}$

\section{THE NATURE OF THE ACTOR}

In the complicated interaction between actor and director (whether professional or not, whether conscious of their means of expression or not), ${ }^{3}$ Pasolini seems to be a master, both in terms of freedom and attention to detail and in terms of the craft of film-making and the communication of something beyond the tangible objectivity of an artwork. 
Pasolini was an avant-garde director but it is important to understand what is meant by this term, because in his case we are dealing with the avant-garde in poetic or poietic terms, rather than in a formalist sense. ${ }^{4}$ Pasolini, who, as he pointed out in a beautiful interview, taught himself filmmaking, always took non-canonical paths - paths that, I think, haven't been fully explored until today. ${ }^{5}$

In this sense, I would like to reflect on some of the recurring 'figures' in Pasolini's cinema. By this I mean, for instance, the use Pasolini makes of actors as stylistic and critical models in which the aesthetic choices show his high ethical standards (which are, again, political in the widest sense of the word). Deliberately applying terms far from the common theoretical classifications used to discuss acting and avoiding the classical problem regarding the interpretation of a role from a psychological point of view, as occurs for instance in the model of the American Actors Studio, I think it is possible to identify three recurring 'types of actors' within Pasolini's work. I focus here on the style of his films, that is, his 'cinematographical writing'.

1) The actor as a self-aware quotation of himself: for instance, Totò in Uccellacci e uccellini (Hawks and Sparrows), where he is 'free to act' within the profound canon of his own craft, or, in a subtractive sense, Maria Callas in Medea, where she is deprived of her divine voice. In my opinion, even a 'heavyweight' performance such as that of Orson Welles belongs in this category. When he is asked to play the role of the director in La ricotta who represents Pasolini, his aura of being a 'huge genius' within the international star system works as a quotation, indeed an ironic one. ${ }^{6}$

2) The actor as symbol of figural nature, the specific incarnation of a concept or model: for example, Silvana Mangano - or rather her face, her perfectly made-up nocturnal eyes - when she plays the character of the mother as Jocasta in the Greek tragedy of Oedipus the King or as a member of the rich, Lombardian bourgeoisie in Teorema. Or the 'stranger' Terence Stamp: after his success in Joseph Losey's Modesty Blaise, Pasolini asked him to play the role of the guest in Teorema, the object of desire and the source of redemption.

3) Finally the actor - by which I mean the actor's body and not his or her 'acting' - as an open stage (palcoscenico aperto): the open stage is the place for the unveiling of the actor's anthropological self , existing before and beyond the cinematic fiction of the part he or she plays. It is a place that broadens the anthropological and geographical boundaries 
of our perception as an audience in the light of Pasolini's political and poetic search for new aesthetic outlooks and perspectives of meaning even, and perhaps primarily, in the Southern parts of the world, which represented for the director a widespread trans-European 'Third World'.

I think that it is through the application of these stylistic forms of the actor's mise en scène that Pasolini's cinema shows its deep anthropological vision and his poetry of resistance. I will leave the first two of these characterizations as simple suggestions, and I hope they may be useful. However, I intend to dwell a little longer on the idea of the actor as an open stage.

\section{REALITY PRESENTS ITSELF}

At this point I think it is important briefly to mention some of Pasolini's theoretical writings, which provide the scenario for my reflections about his use of the actor. The direct textual references come from the collection Empirismo eretico. These texts are (in)famous for their complexity and ambivalence, which led to many debates amongst semiologists and non-semiologists alike. My overview of them focuses on specific aspects, in a broadly philosophical sense, which seem to have a significant impact on the question of the nature and function of the actor as a 'linguistic fragment of reality'. I shall not deal with the issues regarding Pasolini's profession and his craft - whatever they may be.

That the figure of the actor allows for such highly metaphysical reflections is 'the secret of Pulcinella', which in Italian means that it is an open secret and has long been apparent, from the Greeks to the paradox of Heinrich von Kleist's puppets to the contemporary incarnation of the concept in the actor Carmelo Bene. With respect to this point, I would also like to recall that Pasolini in Empirismo eretico tells us repeatedly that he would like to write a philosophy of cinema (thinking in particular of certain aspects and consequences that arise from the assumption of an all-governing code of reality); on the other hand, he also warns professional 'philosophers' that his approach to reality and knowledge is surely not a contemplative one (nor a particularly philosophical one in the traditional academic sense).

On the contrary, in the case of cinema Pasolini speaks explicitly and provocatively of a passion for reality; a desirous and poetic/poietic passion. This passion, he writes, must be understood as something that 
can be transformed from love for an object into an obsession. (And with this we are right in the middle of Pasolini's cinematographic world and of a phenomenology of love that is closely watched over by the guardian angel Roland Barthes.) It is an attitude - also a cinematographic attitude - that leads to the suspension of time in the intensity of the gaze, which is perceptive and expressive and goes beyond any visual mimesis. It is an aesthetic and erotic, perceptive and intellectual vision; from a subjective position, it is also is also 'extreme' - if you wish to call it that - in its ability not only to perceive the object in its obsessive quality but also to depict it for others.

On the topic of his 'cinema of poetry', Pasolini wrote:

Il 'cinema di poesia' [...] ha dunque in comune la caratteristica di produrre film dalla doppia natura. Il film che si vede e si percepisce normalmente è una 'soggettiva libera indiretta', magari irregolare e approssimativa molto libera, insomma dovuta al fatto che l'autore si vale dello 'stato d'animo psicologico dominante nel film' - che è quello di un protagonista malato, non normale - per farne una continua mimesis - che gli consente molta libertà stilistica anomala e provocatoria.

Sotto tale film, scorre l'altro film - quello che l'autore avrebbe fatto anche senza il pretetso della mimesis visiva del suo protagonista: un film totalmente e liberamente di carattere espressivo-espressionistico.

Spia della presenza di tale film sotterraneo non fatto, sono, appunto, come abbiamo visto nelle analisi particolari, le inquadrature e i ritmi di montaggio ossessivi. Tale ossessività contraddice non solo la norma del linguaggio cinematografico, comune, ma la stessa regolamentazione interna del film in quanto 'soggettiva libera indiretta'. È il momento, cioè, in cui il linguaggio, seguendo un'ispirazione diversa e magari più autentica, si libera della funzione, e si presenta come 'linguaggio in se stesso', stile. ${ }^{7}$

The desiring quality of Pasolini's philosophical and artistic attitude is constant in all his works. In the complex, not to say hazardous, theoretical network of Empirismo eretico, the central theme is the relationship between cinema and reality, which the author presents in a reflexive and self-reflexive way, in the manner of an artist's poietical reflection. The principal axiom set up by Pasolini is that 'cinema' is a langue and the individual 'films' are the paroles in Saussure's sense. ${ }^{8}$ This axiom is combined with the supposition, full of philosophical and metaphysical meaning, that this langue/cinema, like a hypothetical continuous long take, is the reality: a reality which expresses itself, in so far as it is per se linguistic as a communicative system. 
In his essay 'Il codice dei codici', in order to make his argument perspicuous, Pasolini tries to create a hypothesis that includes the existence of God/Brahma, a 'vedic/Spinozan' entity, in which ancient Indian traditions mingle with Spinoza's res cogitans (the thinking material). And remaining within the boundaries of this mental experiment, he can define reality simply as B's (Brahma's) language. To begin his argument, Pasolini introduces Umberto Eco, his interlocutor in the text, and us to a blond Neapolitan boy:

Un giovane biondo, caro Eco, avanza verso di te. Non ne senti l'odore. Forse perché non ce l'ha, o perché è lontano, o perchè altri odori formano un diaframma tra te e lui, o forse perché tu hai il raffreddore. Strano, perché un certo odore dovrebbe averlo, addosso. È biondo, ti dico: ma il suo biondo è leggermente fuligginoso, come striato di patine avite, neglette ed escluse dal biondo barbarico e borghese dei grandi paesi ricchi del nord. Non lo si direbbe razzialmente biondo. Uno scherzo forse del destino. O, forse, qualche corno di qualche sua brava, struggente madre dall'albero genealogico sconosciuto (Degli Esposti, Degli Innocenti, Degli Angeli, Dei Morti di Fame) perpetrato con qualche soldato di soldatesche straniere, prezzolate e fredde.

Questi capelli biondi sono troppi, formano un colbacco; ma il vento ha disfatto quel colbacco, e ne è rimasto un alto pennacchio che (adesso che il vento è caduto) forma un piccolo monumento sproporzionato al viso minuto. Il minuto viso ha occhi smarriti. Devono essere castani, ma lo struggimento li rende opachi, e sembra riempirli del giallo dei vecchi mali proletari. ${ }^{9}$

Pasolini imagines and describes the meeting between Eco, a philosopher and semiologist, and a young Neapolitan proletarian boy. In order to further complicate this mental puzzle, he then wants us, the readers, to remain uncertain in the same manner as his interlocutor Eco. Perhaps, Pasolini tells us, Eco does not 'perceive' this blond boy in terms of a real encounter; perhaps it is instead like seeing him in a film ${ }^{10}$. We, the essay's readers, could easily see or imagine the scene's being filmed or described or even experienced: Umberto Eco meets Jerry Malaga - since that's what the blond boy is called. When the detailed description of the meeting ends, Pasolini asks himself:

Ma che differenza c'è tra i capelli di Jerry Malaga e gli occhi di Umberto Eco? Essi non sono che due organismi della realtà, la quale è un continuum senza alcuna soluzione di continuità. Un corpo unico, ch'io sappia. I capelli di Jerry Malaga e l'occhio di Umberto Eco appartengono dunque 
allo stesso Corpo, la fisicità del Reale, dell'Esistente, dell'Essere; e se i capelli di Jerry Malaga sono un oggetto che si 'autorivela' come 'segno di se stesso' agli occhi ricettori di Umberto Eco, non si può dire che si tratti di un dialogo, ma di un monologo che il Corpo infinito della Realtà fa con se stesso. ${ }^{11}$

Only at the end of the text do we come to understand that the meeting between the philosopher and the blond boy did not happen in real life, nor in a film, but in a play. Eco meets Jerry Malaga on the stage. Malaga, therefore, is an actor. As an object/subject, the actor, in a perpetual shifting of meaning, still remains an 'object in/of reality' - someone we see both as what he is and, at the same time, as what he represents. $\mathrm{He}$ was chosen by the director on the basis of that which he himself is to interpret as well as on the basis of his capacity to act out a part.

I won't spend more time on this topic here, but one cannot miss the fact that in this text and elsewhere in Pasolini's writings there is a certain similarity to Spinoza's concept of Deus sive natura (including 'natural thinking'), which is explicitly quoted by Pasolini as a theoretical and philosophical refuge for the artist - the artist who, as in the case of Brahma, seems to be an atheist, but at the same time is easily able to imagine a god as the creator of the world, a god/world/reality and a language of that world/reality. He can therefore also believe in and think of a language of the cinema, a language of reality, as a divine (hierophantic) language wherein reality reveals itself. Within the continuum that is cinema (reality/language), Pasolini tells us that films are an organization and manifestation of that reality. An organization and manifestation of reality is all that we are in fact able to perceive. And this manifestation is primarily created by a temporal, subjective and stylistic construction: the montage.

In discussing the theme of realism or naturalism (according to Pasolini, a question of stylistic nature, in the sense that cinematic language does not have a grammar but rather a style), he warns us that absolute cinema, the concept of cinema as langue (as a mental exercise) would lead us to the insignificance of being; more precisely, we would experience the insignificance of being. (The fixed camera shooting everything that passes in front of its lens. Cinema as an infinite long take.) The fear of this absolute naturalism, Pasolini writes, is equivalent to the fear of being, the fear of the continuum (insignificance), whereas a film, applying different technical means, above all montage, is able to originate an internal temporality, a conclusion, a death, a meaning: 
Praticamente dunque, la questione della differenza tra vita reale e vita riprodotta, cioè tra realtà e cinema, è dunque una questione, come dicevo, di ritmo temporale. Ma è una differenza di tempi che distingue anche cinema da cinema. La durata di una inquadratura. O il ritmo del succedersi delle inquadrature, muta il valore del film: lo fa appartenere ad una scuola anziché a un altra, a un'epoca anziché a un altra, a una ideologia anziché a un altra. ${ }^{12}$

In what sense can the generalizations in this semiological and philosophical discussion, together with the allusions to Spinoza, be useful in the context of our original discussion about the actor and our further reflections about his or her anthropological character? In other words, what are the consequences for the concept of the actor that arise from Pasolini's vision, Saussure's ideas, and Spinoza's hypothesis about a continual monologue that reality has with itself?

Before looking for some possible answers to this question, I would like to point out two other aesthetic and theoretical arguments which Pasolini discusses in Empirismo eretico: the tension involved in the importance of framing in cinema and the influence of the pictorial view which he adopted during his artistic education.

According to Pasolini, the first syntagm or piece of cinematographical writing that makes up the film consists of the frame (the shot). In order not to fall into the trap of formalism, he underlines repeatedly not only how the single take of the camera is the substantial and necessary frame (the shot), but also how the objects of the shot - the reality - are equally important. We can change the camera take, but the camera is still always filming objects (or people). In Gennariello in his Lettere luterane, Pasolini pauses to describe the importance of props. With the use of precise objects in cinema (furniture, the coffee cup from a certain period) a historical, psychological, and aesthetic message can immediately and clearly be communicated. This can also be seen in one of the many anecdotes which theatre people pass around: when Luchino Visconti was directing a Chekov play, he insisted on having 'authentic' nineteenth-century suitcases on stage instead of copies - even if they were made by the best artisans.

Amongst the things we see in a shot, needless to say, are the actors. They are subjects or objects, like other things, but they have a certain quality, a certain weight. In what sense? Let us take a look at a quote from Pasolini: 
Quello che io ho in testa come visione, come campo visivo, sono gli affreschi di Masaccio, di Giotto - che sono i pittori che amo di più, assieme a certi manieristi (per esempio il Pontormo). E non riesco a concepire immagini, paesaggi, composizioni di figure al di fuori di questa mia iniziale passione pittorica, trecentesca, che ha l'uomo come centro di ogni prospettiva. Quindi, quando le mie immagini sono in movimento, sono in movimento un po' come se l'obiettivo si muovesse su loro come sopra un quadro; concepisco sempre il fondo come il fondo di un quadro, come uno scenario e, per questo, lo aggredisco sempre frontalmente. ${ }^{13}$

If you consider the final sequences of Mamma Roma, we have a long take that focuses on the dying Ettore. The boy is in agony, strapped to a table in the prison. ${ }^{14}$

Ettore's body in the film is clearly rooted in its anthropological and sociological dimension as that of a subproletarian country boy who has been taken to the city and urbanized. At the beginning of Mamma Roma, Pasolini focuses on the 'ancient' face of the actor, which resembles some vague traits of Caravaggian paintings, and on his skinny body as he moves along in his indolent and insecure stroll. The director eventually shows us this body in the 'urban' context, dressed in an ironed white shirt - evidently a sad costume, in accord with his mother's dream of being petit-bourgeois. Mother and son dance together like a newly married couple in their new flat in the Roman suburbs: a petit-bourgeois metamorphosis, but for Ettore one without a transformation of the flesh. And thus Ettore's sociologically defined body becomes, in the movie's final scenes, the body of the (religious?) 'passion'. He undresses; in a sense, he lets his social stigmata slip off, without eliminating them, and - with the fundamental aid of the music - steps over the threshold into the transcendence of Ecce homo. Through Ettore's body - the actor's body - a door is thrown open to a reality that is no longer solely sociological, historical, and political. It leads him to the world of dreams, irrational, religious, violent, and primitive, which has been the backdrop of the film throughout, like a shadow. 
THE BODY OF THE ACTOR IN PERFORMANCE/THE ACTOR AS AN OPEN STAGE/A DIACHRONIC AND TRANSCULTURAL VIEW

One of the points I want to examine more closely is the fact that Pasolini, through his insistence on the body of the actor, introduces with expressive force - even violence - a temporal, diachronic element into the ideal continuum of the cinema and the stylistic rhythm of the film. In an expressive and not a mimetic way, Pasolini enhances 'reality' and rips it apart. With a focus on the body of the actor, even before any consideration the way he or she acts in the role, Pasolini lunges forward: a cut appears in the canvas of the painting and therefore also in the temporality of the film, in the flow of the cinematic linguistic reality. (This is part of the Zeitgeist or spirit of the times: Gilles Deleuze defines the focus on the body of the actor in cinema as one of the characteristics of art cinema or avant-garde cinema of the period. $)^{15}$

Each actor caught by the camera actually reveals himself or herself as something beyond his or her role in the drama, as an autonomous landscape, a unique world, an original, many-layered reality - an open stage of events that are not linear and are even unexpected. We can speak of the emergence of the past and the appearance of something lying beyond, as well as the emergence of a system of temporal and geographical coordinates which differ from those imposed by the so-called 'white man from the West', whom Pasolini often criticizes.

With the focus on the actor, there emerges a depth of memory within the ideal continuum of cinema/reality and within the temporality that is defined stylistically by the film (primarily due to montage). For Pasolini this memory is, however, one which always negates any reconstruction that would speak of victorious cultures in opposition to cultures that have vanished or that now seem insignificant. We must not forget that this position free of the limitations of time and space lies at the heart of 'our culture' when it is seen from a critical point of view.

The camera's freezing on the body of the actor at a significant moment when the action is suspended - often heightened by the use of music - becomes a constant stylistic device and, at the same time, a philosophical moment. It is an intellectual desire and obsession that transforms this body into a sacred portal, a threshold, as has already been mentioned. In less mystical terms, we could think of the typical image of a collection of Chinese boxes. 
What happens to the actor - this particular fragment of reality, who, by a convention that is accepted on the part of the audience, is supposed to represent something other - in this theoretical and aesthetic context? Is this, or should this be, something other than his or her own, as it were, natural self? My hypothesis is that, when faced with this crux, Pasolini is revealed to be a master at providing anthropological freedom to his actors - even if this appears to be a paradox, given his severe attention to stylistic features. It is evident that the metaphysical question underlying the nature of the actor and his or her function which is therefore a question about perceived reality - is openly presented in his cinema. It stretches from the Brechtian criticism of the actor's psychological identification that characterizes the Notes for an African Oresia and the Gospel According to Matthew to the fixed iconic status of a Medea/Callas 'deprived of her voice', to Silvana Mangano's abyssal stare and to Massimo Girotti's bourgeois interpretation of the industrialist in Teorema and even Totò's previously mentioned codified and self-referential performance in Hawks and Sparrows (in which he acts in his natural style, giving a performance full of the elements of traditional comic artistry). In an interview Ninetto Davoli recollects how Pasolini would allow him to do whatever he wanted; thus, he acted as he liked. These are only a few examples; the list could continue. In a certain sense the actor is left alone, naked, consigned to his or her reality in front of the audience. (Here we are approaching one of the political aspects, in Rancière's sense, of Pasolini's art.) And in light of what has been said, Pasolini can propose, as he does in Notes for an African Orestia, Black American culture within the White world - that is, their music - as a way of representing, in today's world, some of the conceptual and political issues contained in Aeschylus' text. He leaves us 'alone' as spectators for rather a long time in front of Gato Barbieri and a group of Black singers jamming in a backstreet studio in New York.

Now I draw my conclusion; it will lead me not to the end of the road, which seems to me as yet only a country path, but rather to the end of my essay. 
When Pier Paolo Pasolini was filming The Gospel According to Matthew in 1965 he met Ninetto Davoli. These lines describe their first meeting:

Ed ecco che entra nella platea un ossesso, con gli occhi dolci e ridarelli vestito come i Beatles.

Mentre grandi pensieri e grandi azioni sono implicati nel rapporto di questi ricchi con lo spettacolo, fatto anche per lui, egli col suo dito magro di cavallino delle giostre, scrive il suo nome 'Ninetto' nel velluto dello schienale ...

$[\ldots]$

Ninetto è un messaggero, e vincendo (con un riso di zucchero che gli sfolgora da tutto l'essere, come in un musulmano o un indù) la timidezza, si presenta come in un areopago a parlare dei Persiani. I Persiani, dice, si ammassano alle frontiere. Ma milioni e milioni di essi sono già pacificamente immigrati, sono qui, al capolinea del 12, del 13, del 409, dei tranvetti della Stefer. Che bei Persiani!

Dio li ha appena sbozzati, in gioventù, come i musulmani o gli indù: hanno i lineamenti corti degli animali, gli zigomi duri, i nasetti schiacciati o all'insù, le ciglia lunghe lunghe, i capelli riccetti (...). ${ }^{16}$

Pasolini fell in love. Pasolini found a body/signifier which was able to evoke something fundamentally important to the director on an anthropological, aesthetical and political level. Speaking again of Ninetto Davoli, Pasolini recounts a philosophical anecdote:

Ninetto per la prima volta in vita sua vede la neve (è di origine calabrese: era troppo piccolo per la nevicata di Roma nel '57, o forse non era ancora venuto dalla Calabria). Siamo appena rarivati a Pescasseroli, le distese di neve l'hanno già fatto gioire di pura sorpresa un po' troppo infantile per la sua etá (ha secidi anni). Ma con lo scendere della notte, il cielo si fa d'improvviso bianco, e, come usciamo dall'albergo per fare due passi nel paesello deserto, ecco che l'aria si anima; per uno strano effetto ottico, 
dato che i fiocchi piccolissimi vanno verso terra, pare di innalzarsi verso il cielo, ma irregolarmente, perché la loro caduta non è continua, un bizzoso vento montano li fa vorticare. Guardando in alto gira la testa. Pare che tutto il cielo ci stia cadendo addosso scigliendosi in quella sagra felice e cattiva di neve appenninica. Figurarsi Ninetto. Nonappena percepisce l'avvenimento mai visto, quello scioegliersi del cielo sulla sua testa, non conoscendo ostacoli di buona educazione alla manifestazione dei propri sentimenti, si abbandona ad una gioia priva di ogni pudore. Che ha due fasi rapidissime: prima è una specie di danza, con delle cesure ritmiche ben precise (mi vegono in mente i Dinka, che battono il terreno col tallone, e che, a loro volta, mi avevano fatto venire in mente le danze greche come si immaginano leggendo i versi dei poeti). Lo fa appena appena, l'accenna, quel ritmo che percuote la terra coi talloni, muovendosi sù e giù sulle gionocchia. La seconda fase è orale: consiste in un grido di gioia orgiastico-infantile, che accompagna le acmi e le cesure di quel ritmo: 'Hè-eh. Hè. Eh, heeeeeeeh'. Insomma un grido che non ha un corrispettivo grafico. Una vocalità dovuta a un memoriel, che congiunge in un continuo senza interruzione, il Ninetto di adesso a Pescasseroli, al Ninetto della Calabria area marginale e conservatrice della civiltà greca, al Ninetto pregreco, puramente barbarico, che batte il tallone a terra come adesso i preistorici, nudi Dinka nel Basso Sudan. ${ }^{17}$

Just as in a film, Pasolini quotes and uses Ninetto as a complex signifier. Alongside Ninetto emerges his subjective, anthropological, socio-political reality; at the same time a broad cultural, temporal, and geographical horizon, which goes beyond his individual objectivity, appears through him.

\section{NINETTO AS AN EXAMPLE OF AN ACTOR/STAGE}

He is identical to himself. He is free to speak as himself in a story which is not his own. Speaking for himself, however, he is also effectively speaking for other worlds, preserving and bringing out their meaning which is still conserved within his body. In the everyday normality of a stroll, as well as in a hypothetical film, Ninetto evokes his distant 'black brothers' who have been studied by anthropologists. As the son of immigrants he embodies, without any need to act, the recent (and even future) immigrants from North Africa, as well as our Homeric heroes (or non-heroes). The director Pier Paolo Pasolini therefore invites us to perform a sort of new Copernican revolution, to experience in corpore vili the human being as the centre of the world. This must necessarily be 
accompanied by a theoretical humility in the face of the emergence of the power of the past and the so-called 'different' and 'unknown'.

I would like to end this piece (although, as I must remind you, these are just notes) by making a comparison. Let's consider a work by another director, who may at first glance seem a world apart from Pier Paolo Pasolini: Woody Allen. Let's remember his The Purple Rose of Cairo. In this sophisticated comedy, Woody Allen presents a paradoxical story. One of the characters from the movie within the film decides to step down from the screen and to start living in the real world. And this world is so 'real' that the young explorer who has escaped from the screen falls in love with a passionate cinemagoer and considers starting a new (real) and happy life with her. This is very disturbing. The other characters, still stuck in the film, are left open-mouthed; in fact they get quite angry. As if that were not enough, it seems that in other movie theatres where the film is being shown the same character, the courageous explorer - who is played, almost too well, by a young actor keen to make it in Hollywood - also has a dangerous tendency to want to live in real life. It is a disaster. What can be done?

The studio seeks out the actor and orders him to intervene and to put a stop to the mess - to the madness. So the actor gets involved. He goes to the town where his character's first defection took place. There the actor arranges for the naive, daydreaming cinemagoer with whom his character fell in love to fall in love with him instead. He convinces her that he, the real reality, is better than the fiction. Because of this, his disappointed cinematic alter ego decides to return to the 'celluloid world' of the movie. All's well that ends well, then?

Not by any means. The young actor, true to his role, leaves the romantic cinemagoer he has just won over (played by Mia Farrow, showing her best old-fashioned innocence) and returns happily to the movie business. Because this is what counts, Woody Allen tells us with bitter irony. At stake here are capitalist economic principles which demand that the fiction must remain what it is. The actors play the characters as best as they can, and the cinemagoers dwell in dreams for a little while in the movie theatres. If his problem had not been resolved, our real actor's career would have been ruined. So at the end we see him, a happy liar, sitting on a plane which will take him back to the Mecca of dreams, Hollywood, to shoot his next movie, while our cinemagoer sits down in front of the screen once again to see the next movie. 
I like the idea that Pier Paolo Pasolini's actors, like his cinema, have an additional freedom and capacity for transgression - that, paradoxically, they are able, in some way, to step in and out of the screen, with our critical and oneiric complicity. Their reality is unique and open, even within the cinematographical fiction, in their director's desire for soggettiva libera indiretta ('free indirect subjectivity' or 'free indirect point-of-view shot') of their director. At least it's nice to think that Pasolini's actors have had, or at least in any case have shown us that there is always another option.

This isn't just the comedy of lies which are told, but also of the truth which isn't told.

(Che cosa sono le nuvole?)

\section{NOTES}

1 If we wanted to map out these coordinates, just to make it clearer, we could start with the following list. In Pasolini's cinema we can find: a) non-professional actors (ordinary people, the proletariat, Italians and non-Europeans, intellectuals, friends, and family members); b) professional actors, including: b1) worldfamous media or art icons (Maria Callas, Anna Magnani, Totò, Orson Welles); b2) actors coming from very different backgrounds such as Massimo Girotti or Hollywood's Terence Stamp, or actors from the French New Wave, such as Godard's wife in Porcile and Teorema; b3) avant-garde theatre actors such as Carmelo Bene or Julian Beck; c) 'Pasolinian' actors such as Ninetto Davoli, Sergio Citti, Mario Cipriani, Laura Betti, and Silvana Mangano (who, in particular, played many of the female roles); and, finally, d) actors and non-actors in his documentary films.

2 This paper assembles preparatory ideas for staging a play in Germany based on Pasolini's works, a performance that is part of a larger series of projects which have already been carried out in Berlin and which explored, amongst other things, the relationship between Pasolini and Dante and the combination of poetry and music in autobiographical narratives.

3 I don't wish to spend time to elaborate now on the differences between directing for the theatre and for cinema. In my opinion, these differences, albeit important, do not alter the deeper theoretical matters discussed here.

4 Think of Pasolini's criticism of avant-garde Italian poetry and on the other side his friendship with Jean Luc Godard.

5 See the film Pasolini l'enragé (1966), directed by Jean André Fieschi.

6 Interviewed by an unwary journalist in the film La ricotta, Orson Welles quotes the following famous text of Pasolini: 'Io sono una forza del Passato. / Solo nella tradizione è il mio amore. / Vengo dai ruderi, dalle chiese, / dalle pale d'altare, dai borghi / abbandonati sugli Appennini o le Prealpi, / dove sono vissuti i fra- 
telli. / Giro per la Tuscolana come un pazzo, / per l'Appia come un cane senza padrone. / O guardo i crepuscoli, le mattine / su Roma, sulla Ciociaria, sul mondo, / come i primi atti della / Dopostoria, / cui io assisto, per privilegio d'anagrafe, / dall'orlo estremo di qualche età / sepolta. Mostruoso è chi è nato / dalle viscere di una donna morta. / E io, feto adulto, mi aggiro / più moderno di ogni moderno / a cercare fratelli che non sono più'.

7 Pier Paolo Pasolini, 'Il cinema di poesia', in Empirismo eretico, in Saggi sulla letteratura e sull'arte, ed. by Walter Siti and Silvia De Laude, 2 vols (Milan: Mondadori, 1999), I, pp. 1482-83. "The "cinema of poetry" [...] thus has the common characteristic of producing films with a double nature. The film that is seen and ordinarily perceived is a "free indirect point-of-view shot." It may be irregular and approximate - very free, in short, given that the filmmaker makes use of the "dominant psychological state of mind in the film," which is that of a sick, abnormal protagonist, in order to make a continual mimesis which allows him great, anomalous, and provocative stylistic freedom. Beneath this film runs another film, the one that the filmmaker would have made even without the pretext of the visual mimesis of his protagonist - a film whose character is completely and freely expressive/expressionistic. Proof of the presence of such an unrealized, subterranean film are, precisely, as we have seen in the specific analyses, the obsessive shots and editing rhythms. This obsessiveness contradicts not only the norm of the common film language, but the very internal organization of the film as a "free indirect point-of-view shot." It is, in other words, the moment in which language, following a different and possibly more authentic inspiration, frees itself of function and presents itself as "language as such" style' (Heretical Empiricism, trans. by Ben Lawton and Louise K. Barnett (Washington, DC: New Academia Publishing, 2005), p. 182).

8 Pasolini underlines in a provocative fashion the deliberate naivety of such semiological/linguistic speech in his heated debate with Umberto Eco.

9 Pasolini, 'Il codice dei codici', in Empirismo eretico, in Saggi sulla letteratura e sull'arte, I, p. 1611. 'A blond young man, my dear Eco, advances toward you. You do not smell him. Perhaps because he has no smell, or because he is far away, or because other others form a barrier between him and you, or perhaps because you have a cold. Strange, because he should have a certain odor on him. $\mathrm{He}$ is blond, I tell you, but is blondness is slightly sooty, as if streaked with ancestral patinas, neglected and exuded from the barbaric and bourgeois blond of the great rich countries of the North. One would not say that he is racially blond. A joke, perhaps, of destiny. Or perhaps some unfaithfulness of some good struggling mother whose genealogical tree is unknown (Degli Esposti, Degli Innocenti, Degli Angeli, Dei Morti di Fame) perpetrated by some soldier of a cold foreign mercenary army. Their blond hair is excessive; it forms what amounts to a fur hat, but the wind has disheveled that fur hat, and only a tall plume has remained, which (now that the wind has died down) forms a small monument out of proportion to the minute face. The minute face has lost eyes. They must be brown, but torment makes them opaque und seems to fill them 
with the yellow of old proletarian ills' (Heretical Empiricism, p. 276; fn. omitted).

10 Or rather - and here the passage is important for understanding the overall extent of Pasolini's philosophical and linguistic vision - Eco can only read Jerry Malaga's description in a text.

11 'Il codice dei codici', p. 1616. 'But what difference is there between the hair of Jerry Malaga and the eyes of Umberto Eco? They are but two organisms of reality, which is a continuum without any break in continuity; a single body, as far as I know. The hair of Jerry Malaga and the eyes of Umberto Eco therefore belong to the same Body, the physical manifestation of the Real, of the Existing, of Being; and if the hair of Jerry Malaga is an object that "reveals itself" as "sign of itself" to the receptive eyes of Umberto Eco, it cannot be said that this is a dialogue; it is a monologue which the indefinite Body of Reality has with itself' (Heretical Empiricism, p. 279).

12 Pier Paolo Pasolini, 'Essere è naturale?', in Empirismo eretico, in Saggi sulla letteratura e sull'arte, I, p. 1567. 'In practical terms, therefore, the question of the difference between real life and reproduced life, that is, between reality and cinema, is a question, as I was saying, of temporal rhythm. But it is temporal differences that distinguish one film from another. The length of a shot, or the rhythm and succession of shots, changes the value of the film: it causes it to belong to one school rather than to another, to one period rather than to another, to one ideology rather than to another' (Heretical Empiricism, p. 241).

13 In Enzo Siciliano, Vita di Pasolini (Milan: Mondadori, 2005), p. 269. 'What I have in my head as a vision, as a visual field, are the frescoes of Masaccio, of Giotto - who are the painters I love the most along with certain Mannerists (for instance Pontormo). And I am unable to conceive images, landscapes, compositions of figures outside of this initial fourteenth-century pictorial passion of mine, in which man stands at the center of every perspective. Therefore, when my images are in motion, it is a little as though the lens were moving on them as over a painting, like a stage set, and for this reason I always attack it frontally' (Enzo Siciliano, Pasolini: A Biography, trans. by John Shepley (New York: Random House, 1982), p. 232).

14 I admit to being amongst those who associate this shot with Mantegna's Dead Christ, but I am also aware that Pasolini at the time denied any such direct reference.

15 See Gilles Deleuze, Cinema 2: L'image-temps (Paris: Minuit, 1985), chapter 8.

16 In Siciliano, Vita di Pasolini, p. 325, and in 'Avvertenza a "Profezia", in Pier Paolo Pasolini, Alì dagli occhi azzurri (Milan: Garzanti, 1965), p. 515. 'Look, here into the orchestra comes a madman, with soft / and merry eyes, / Dressed like the Beatles. / While great thoughts and great actions / are implied in the relation of these rich people to the film spectacle, / made for him too, he, twirling one thin finger like a merry-go-round horse, / writes his name "Ninetto" / on the back of the velvet seat. [...] / Ninetto is a herald, / and overcoming (with a sweet laugh / that blazes from his whole being / as a Muslim or a Hindu) / his shyness, / he introduces himself as in a Aeropagus / to speak of the Persians. / The Per- 
sians, he says, are massing on the frontiers. / But millions and millions of them have already peacefully immigrated, / they are here, waiting for the No. 12, the No. 13, the No. 409 tram / of the Stefer line. What beautiful Persians! / God has just sketched them, in their youth, / like the Muslims or the Hindus: / they have the short lineaments of animals, / gaunt checkbones, flattened or upturned little noses, / long long eyelashes, curly hair' (translation in Siciliano, Pasolini: A Biography, pp. 284-85).

17 Pasolini, 'Dal laboratorio (Appunti en poète per una linguistica marxista)', in Empirismo eretico, in Saggi sulla letteratura e sull'arte, I, pp. 1331-32. 'Ninetto [...], who sees snow for the first time in his life (he is Calabrese: he was too little for the snowfall of '57 in Rome, or perhaps he hadn't yet come from Calabria). We have just arrived in Pescasseroli, the expanses of snow have already made him rejoice with a pure surprise a little too childish for his age (he's sixteen). But with the advent of night the sky suddenly becomes white, and, as we leave the hotel to take a stroll in the deserted town, suddenly the air becomes alive; because of a strange optical effect, since the tiny flakes are going toward the earth, it seems as if they are rising toward the sky, but irregularly, because their fall is not continuous, a capricious mountain wind makes them whirl. Looking up makes your head spin. It seems that the whole sky is falling on us, disintegrating in that happy and stormy feast of Apennine snow. You can imagine Ninetto. No sooner has he perceived the never-before-seen event, that disintegration of the sky on his head, not knowing the obstacles of proper upbringing to the manifestation of his own feelings, he abandons himself to a completely shameless joy. It has two very rapid phases; first, it is a kind of dance, with very precise rhythmic caesuras (I am reminded of the Dinka, who strike the ground with their heels, and who, in turn, had made me think of Greek dances, as we imagine them when reading the verses of the poets). He does it scarcely at all, hints at it, that rhythm that strikes the ground with his heels, moving the knees up and down. The second phase is oral: it consists of an orgiastic-infantile shout of joy that accompanies the high points and caesuras of that rhythm: "He-eh- he-he, heeeeee." In short, a shout that does not have a written equivalent. A vocalization due to a memoriel which joins in a continuity without interruption the Ninetto of now at Pescasseroli to the Ninetto of Calabria - marginal area and custodian of Greek civilization - to the pre-Greek, purely barbaric Ninetto, who strikes his heel on the ground as the prehistoric nude Dinka now do in the lower Sudan' (Heretical Empiricism, p. 67). 
Agnese Grieco, 'The Body of the Actor: Notes on the Relationship between the Body and Acting in Pasolini's Cinema', in The Scandal of Self-Contradiction: Pasolini's Multistable Subjectivities, Geographies, Traditions, ed. by Luca Di Blasi, Manuele Gragnolati, and Christoph F. E. Holzhey, Cultural Inquiry, 6 (Vienna: Turia + Kant, 2012), pp. 85-103 <https://doi.org/10.37050/ci-06_05>

\section{REFERENCES}

Deleuze, Gilles, Cinema 2: L'image-temps (Paris: Minuit, 1985)

Pasolini, Pier Paolo, Ali dagli occhi azzurri (Milan: Garzanti, 1965)

Heretical Empiricism, trans. by Ben Lawton and Louise K. Barnett (Washington, DC: New Academia Publishing, 2005)

_ Saggi sulla letteratura e sull'arte, ed. by Walter Siti and Silvia De Laude, 2 vols (Milan: Mondadori, 1999)

Siciliano, Enzo, Pasolini: A Biography, trans. by John Shepley (New York: Random House, 1982) 